Review Article

\title{
Promising High-Yielding Tetraploid Plantain-Bred Hybrids in West Africa
}

\author{
Abdou Tenkouano, ${ }_{1}^{1}$ Niéyidouba Lamien, ${ }^{1}$ Josephine Agogbua, ${ }^{2}$ Delphine Amah, \\ Rony Swennen, ${ }^{4}$ Siaka Traoré, ${ }^{5}$ Deless Thiemele, ${ }^{5}$ Ngoran Aby, ${ }^{5}$ Kouman Kobenan, ${ }^{5}$ \\ Goly Gnonhouri, ${ }^{5}$ Ndrin Yao, ${ }^{5}$ G. Astin, ${ }^{5}$ Séraphine Sawadogo-Kabore, ${ }^{6}$ Vianney Tarpaga, ${ }^{6}$ \\ Wonni Issa, ${ }^{6}$ Bernadin Lokossou, ${ }^{7}$ Adolphe Adjanohoun, ${ }^{7}$ Gilles Léandre Amadji, ${ }^{7}$ \\ Solange Adangnitode, ${ }^{7}$ Kabore Alice Djinadou Igue, ${ }^{7}$ and Rodomiro Ortiz ${ }^{\mathbb{D}}{ }^{8}$ \\ ${ }^{1}$ CORAF, 7 Boulevard du President Habib Bourguiba, Dakar BP 48, Senegal \\ ${ }^{2}$ International Institute of Tropical Agriculture, IITA Road, Onne Eleme LGA, Rivers State, Nigeria \\ ${ }^{3}$ International Institute of Tropical Agriculture, PMB 5320, Oyo Road, Ibadan 2001, Oyo State, Nigeria \\ ${ }^{4}$ International Institute of Tropical Agriculture, Plot No. 25 Mikocheni Light Industrial Area, Mwenge-Coca-Cola Road, \\ Mikocheni B, c/o AVRDC-The World Vegetable Center, P.O. Box 10, Duluti, Arusha, Tanzania \\ ${ }^{5}$ Centre National de Recherche Agronomique de Côte d'Ivoire, Km 17, Route de Dabou, Adiopodoumé, Elfenbenskusten, \\ 1 BP 1740 Abidjan 01, Côte d'Ivoire \\ ${ }^{6}$ Institut de l'Environnement et de Recherches Agricoles, 04 BP: 8645 Ouagadougou 04, Rue Guisga, Ouagadougou, Burkina Faso \\ ${ }^{7}$ Institut National des Recherches Agricoles du Bénin, 01 BP 884 Cotonou, Benin \\ ${ }^{8}$ Swedish University of Agricultural Sciences, Department of Plant Breeding, Box 101 Sundsvagen 10, SE 23053 Alnarp, \\ Uppsala, Sweden
}

Correspondence should be addressed to Rodomiro Ortiz; rodomiro.ortiz@slu.se

Received 19 August 2018; Accepted 6 March 2019; Published 21 April 2019

Academic Editor: David Clay

Copyright ( 2019 Abdou Tenkouano et al. This is an open access article distributed under the Creative Commons Attribution License, which permits unrestricted use, distribution, and reproduction in any medium, provided the original work is properly cited.

\begin{abstract}
The devastating threat of black leaf streak disease caused by Pseudocercospora fijiensis on plantain production in West Africa spurred the development of resistant hybrids. The goal of this research and development (R\&D) undertaken was assessing the development and dissemination of two plantain hybrids PITA 3 and FHIA 21 bred in the 1980s by the International Institute of Tropical Agriculture (IITA, Nigeria) and the Fundación Hondureña de Investigación Agrícola (FHIA, Honduras), respectively. In Côte d'Ivoire, plantain growers selected PITA 3 and FHIA 21 based on their improved agronomic characteristics and, between 2012 and 2016, they were massively propagated and distributed to farmers in Benin, Burkina Faso, Côte d'Ivoire, and Togo under the West Africa Agricultural Productivity Program (WAAAP) coordinated by the West and Central Africa Council for Agricultural Research and Development (CORAF). In 2016, the Centre National de Recherche Agronomique in Côte d'Ivoire included the hybrids in the improved cultivar directory. This R\&D activity illustrates how three decades of crossbreeding, selection, and distribution led to local acceptance. It also highlights how a CORAF-led partnership harnessed CGIAR research for development. The dissemination and acceptance of these plantain hybrids will enhance the sustainable intensification in plantainbased farming systems across the humid lowlands of West and Central Africa.
\end{abstract}

\section{Introduction}

Plantain (Musa spp. AAB) is an important starchy staple triploid $(2 n=3 x=33)$ crop and a key component of the farming systems in the humid lowland ecologies of West and Central Africa. This region harbors the world's greatest variability of plantains since they have been cultivated for about 2500 years, and it is, therefore, considered a secondary centre of plantain diversification [1-3]. In addition to being a staple food for rural and urban consumers, plantain is also a source of income for the smallholders [4] who produce them in backyards where application of manure and household 
refuse ensures continuous high productivity for many years $[5,6]$. Plantains are also produced in fields under shifting cultivation and bush fallow with bunch yields declining rapidly after the first production cycle due to disease pressure and poor management practices. Although fruit is produced throughout the year, the major harvest comes in the dry season spanning the months of December through March, when most other starchy staples are in short supply or difficult to harvest [7]. Hence, plantain plays an important role in bridging the hunger gap $[5,8]$. Africa is one of the major plantain-producing continents of the world, accounting for approximately $62 \%$ of worldwide production. Plantain is the third most important crop in Nigeria [4], Ghana [9], and eastern Democratic Republic of Congo [2]. Similarly, in Côte d'Ivoire, the production of plantains is estimated at 1.6 million metric tons (MT), thus making it the third food crop after yam and cassava. In West Africa, the major producing countries are Cameroon (4.5 million $\mathrm{t}$ ), Ghana (4 million $\mathrm{t}$ ), Nigeria (3.2 million $\mathrm{t}$ ), and Côte d'Ivoire (1.6 million t) [2], while Ghana, Côte d'Ivoire, and Cameroon having the highest per capita plantain consumption, 92, 83 , and $72 \mathrm{~kg}$, respectively [10].

Despite the economic importance of plantains in the humid lowlands of West and Central Africa, the sustainable production is threatened by pathogens and pests, posing a risk to household income generation and food security [11]. Black leaf streak disease (also called black sigatoka or black sigatoka leaf disease) caused by Pseudocercospora fijiensis [12] is the most serious production constraint with edible yield loss ranging from $33 \%$ to $50 \%$ in the first crop cycle and $100 \%$ in subsequent ratoons $[13,14]$. Other key pests are the banana weevil (Cosmopolites sordidus) $[11,15]$ and various parasitic nematodes [11]. These pests destroy the corm and root system, thereby reducing anchorage, nutrient, and water uptake, and provide entry points for pathogens $[5,11]$. Increase in population pressure which has led to shortened fallow periods and declining soil fertility is also a constraint in large-scale plantain production. Breeding plantains for host plant resistance to pathogens and pests has been regarded as the most appropriate control strategy since chemical control is expensive and environmentally hazardous for the subsistence growers in the region. Plantain hybrids with host plant resistance to black leaf streak disease and other pests plus good agronomic characteristics have been developed by breeding programs such as the International Institute of Tropical Agriculture (IITA), the Centre Africain de Recherches sur Bananiers et Plantains (CARBAP) in Cameroon, and the Fundación Hondureña de Investigación Agrícola (FHIA) in Honduras [16-18]. The development of these plantain hybrids is a major achievement by breeders since triploid plantains $(2 n=3 x=33$ chromosomes) were generally considered intractable to genetic improvement due to their triploid nature which results in almost complete sterility [16].

Plantain breeding in IITA began in 1987, and within five years of breeding, 20 tetraploid tropical Musa plantain hybrids (TMPx) were developed and fourteen of the best hybrids were registered in the public domain [19]. In 1994, IITA received the $7^{\text {th }}$ King Baudouin Award in recognition of its contribution to breeding plantains for black leaf streak resistance and advances in Musa genetics. IITA in collaboration with national partners evaluated these hybrids in several African countries for edible yield and its stability across sites and cropping cycles along with durability of host plant resistance to $P$. fijiensis [20]. Several hybrids were selected as promising for further cultivar release in West African countries [21, 22].

In West Africa, improved plantain hybrids bred by IITA (PITA 3) and FHIA (FHIA 21) are increasingly being grown by farmers due to their resistance to pathogens and pests, edible yield and stability, rapid cycling, and acceptable fruit processing attributes. PITA 3 and FHIA 21 have been released as new cultivars in Côte d'Ivoire and are grown by farmers in Benin, Burkina Faso, and Togo after a series of multilocation evaluation trials. This paper highlights the development and dissemination of these two plantain tetraploid hybrids in francophone, West Africa, which was implemented and coordinated by West and Central Africa Council for Agricultural Research and Development (CORAF) under the West Africa Agricultural Productivity Program (WAAPP).

\section{Producing and Sharing Plantain Hybrids for West Africa}

2.1. Hybrid Origin. The development of IITA plantain tetraploid hybrids $(2 n=4 x=44)$ was described previously [23]. A total of 113 plantain cultivars were screened for female fertility but the tetraploid plantain hybrids were derived from only four cultivars ("Bobby Tannap," French Reversion, "Mbi-Egome," and "Obino L'Ewai") that belong to the French plantain subgroup [23, 24]. PITA 3 is a plantain hybrid that was produced by crossing the seed fertile medium size "Obino L'Ewai" and the wild diploid $(2 n=2 x=22)$ banana "Calcutta 4." This cross made in November 1989 at the IITA High Rainfall Station in Onne (southeastern Nigeria) produced 41 seeds. The seeds were germinated in vitro and TMPx 5511-2 (later released as PITA 3) was selected after early evaluation and preliminary yield on-station trials (Figure 1). From 1993 to 1995, PITA 3 was evaluated alongside other 11 promising tetraploid hybrids in multilocational evaluation trials (METs) in Cameroon, Ghana, Nigeria, and Uganda for the production stability and adoption across environments [20]. PITA 3 was further included in advanced testing along with eight tetraploids in the first IITA's advanced Musa yield trial (AMYT) in Burundi, Côte d'Ivoire, Ghana, Kenya, Nigeria, and Zanzibar. The hybrids in AMYT were evaluated over a period of two cropping cycles (mother plant and ratoon) in a randomized complete block design with four replications of five plants each and plant spacing of $3 \mathrm{~m} \times 2 \mathrm{~m}[6,20]$. The objective was to identify elite bred germplasm for potential release as new cultivars by each country according to their specific regulations.

FHIA 21 is a French plantain hybrid developed by the FHIA breeding program at La Lima (Honduras) from a cross between the French plantain AVP-67 and the diploid banana SH-3142 in 1983 (Figure 2). It was selected in 1986 from 


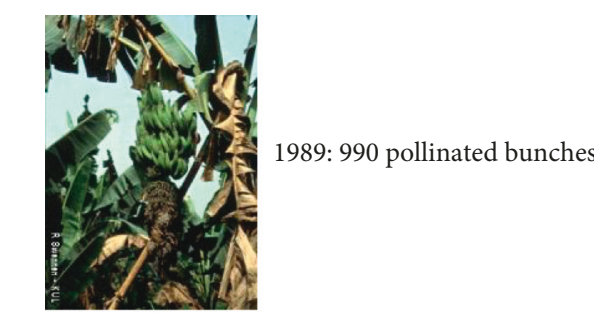

$3 x$ plantain cv. "Obino L'Ewai"

$\times$

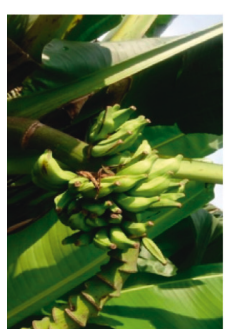

4871 seeds

1990: In vitro seed germination

$2 x$ wild banana "Calcutta 4 "
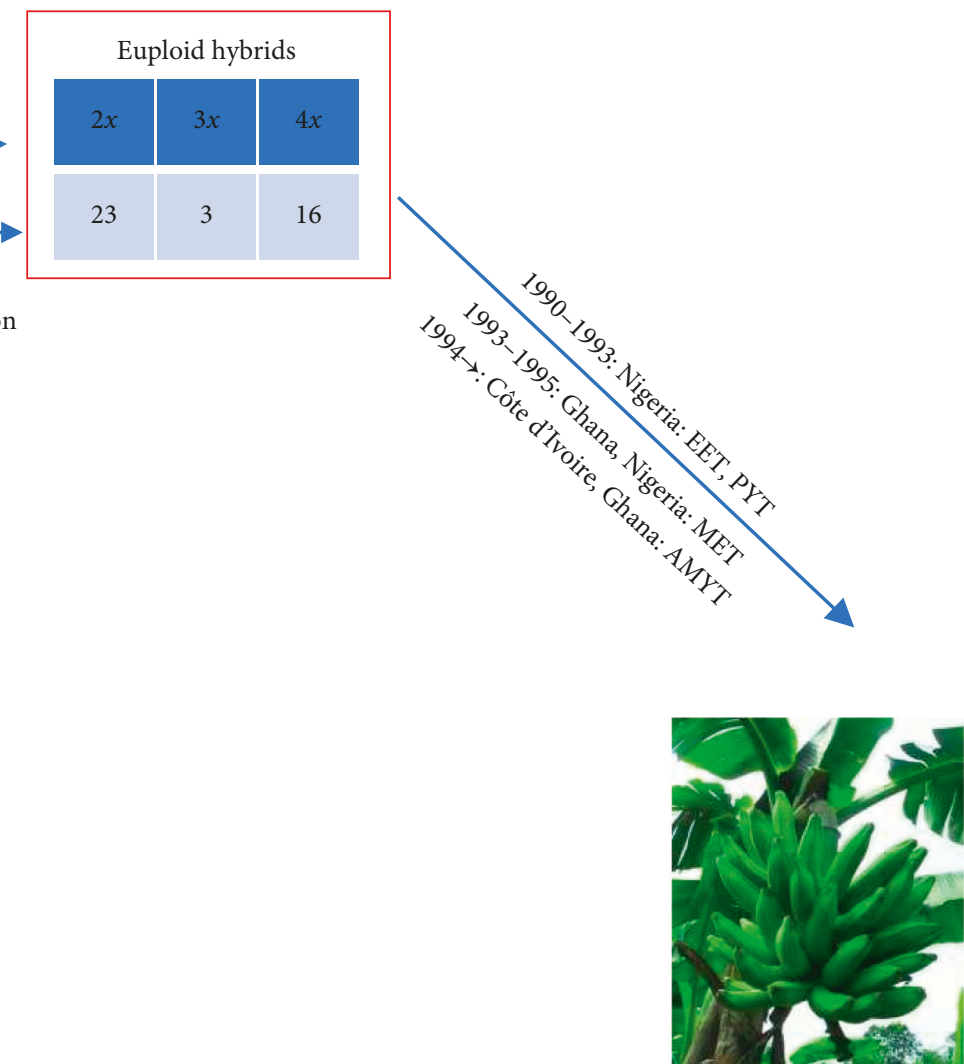

$4 x$ plantain hybrid "PITA 3 "
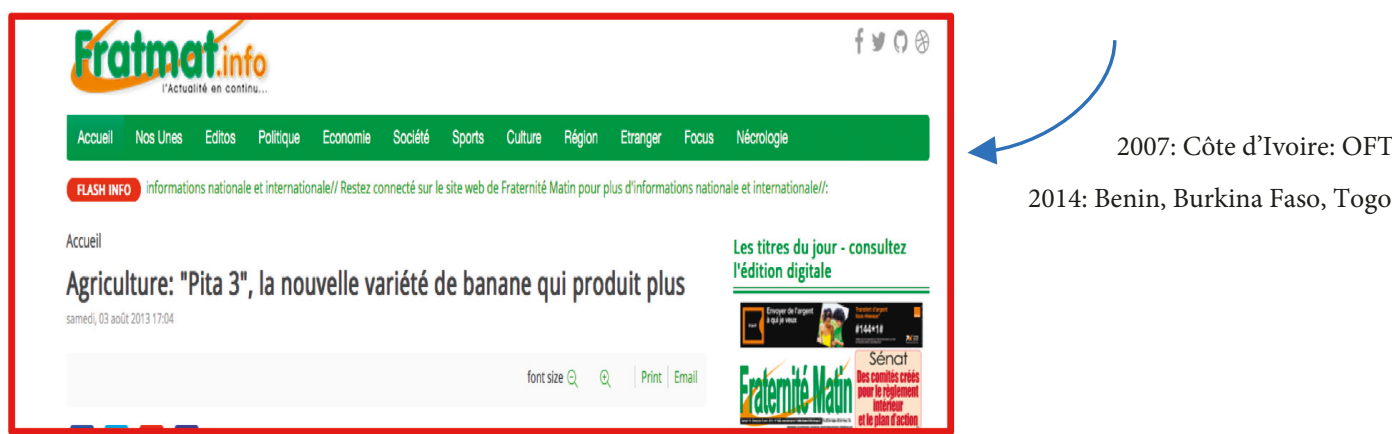

2014: Benin, Burkina Faso, Togo: AMYT

Accueil

Les titres du jour - consultez

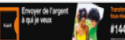

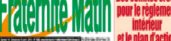

FIGURE 1: The making of "PITA 3"- a tetraploid ( $4 x$ ) primary hybrid bred by the International Institute of Tropical Agriculture (IITA, Nigeria) in partnerships with Council for Scientific and Industrial Research/Ministry of Food and Agriculture/University of Ghana (Ghana), Centre National de Recherche Agronomique (Côte d'Ivoire), Institut de l'Environnement et de Recherches Agricoles (Burkina Faso), and Institut National des Recherches Agricoles du Benin (Benin) - as a new plantain cultivar for West Africa. Source for crossing data: [18, 19, 22]. November 1989: crossing; 1990-1991: EET =early evaluation trial using nonreplicated plots of 3 or 4 plants; 1992-1993: PYT = preliminary yield trial with 2 replications of 4 or 5 plants; 1993-1995: MET = multilocational environmental trial with 2 replications of 5 plants across at least 2 sites and over 2 crop cycles; 1994 onwards: AMYT =advanced Musa yield trials as per MET but also testing crop husbandry practices; 2007 onwards: OFT =on farm testing of hybrid(s) along with crop husbandry prior cultivar release in Côte d'Ivoire (2017).

several first-generation seedlings. SH-3142 is a bred diploid derived from crossing the $\mathrm{SH}-1734$ bred diploid onto the diploid "Pisang Jari Buaya" banana, collected in Papua New Guinea. The diploid bananas from the FHIA genebank included in the pedigree of SH-1734 are "Lidi," "Sinwobogi," and the wild fully-seeded Musa acuminata subsp. errans wild, which were collected in Sumatra, Papua New Guinea, and the Philippines, respectively. 


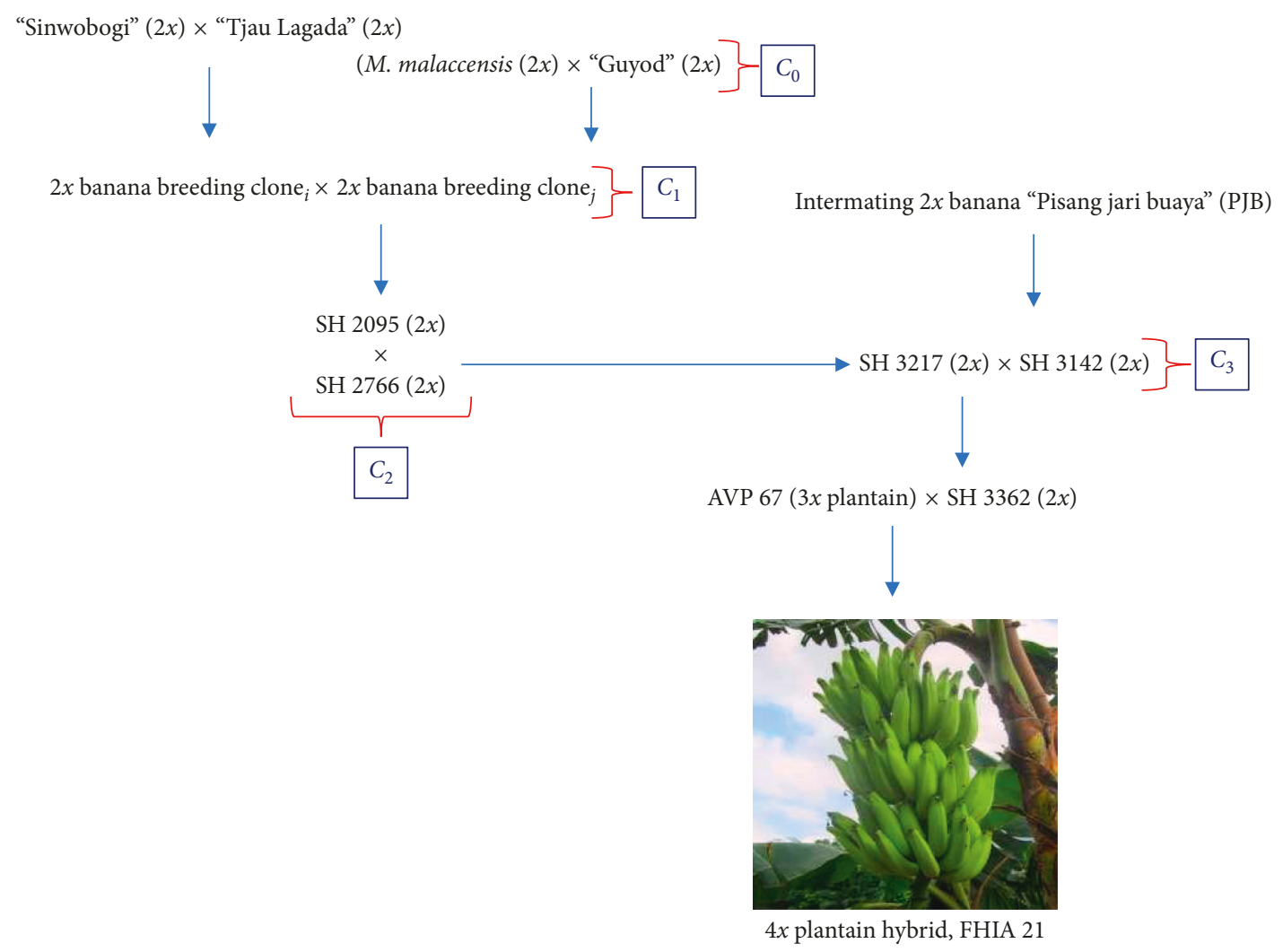

Figure 2: Development of primary tetraploid ( $4 x$ ) "FHIA 21" by FHIA, Honduras, which was, after further multilocation testing in West Africa, released as a new cultivar in Benin, Burkina Faso, Côte d'Ivoire, and Togo, as well as named "Apem hemaa" in Ghana. Its male diploid $(2 x)$ banana parent ensued after three cycles of phenotypic recurrent selection $\left(C_{i}\right)$ at $2 x$ ploidy level in Honduras with a germplasm influx from "Pisang jari buaya" in $C_{3}$ and interploidy crossing with triploid ( $3 x$ ) plantain AVP-67 (code for a plantain grown in Honduras and available at FHIA genebank). Source for pedigrees of $2 x$ bananas in $C_{i}$ : [25]. Although the year for each activity was unavailable, the timeframe from crossing $\left(C_{0}\right)$ in Honduras to release of FHIA 21 for worldwide distribution was about 30 years.

Following a participatory selection trial in western Côte d'Ivoire in 2007, FHIA 21 and PITA 3 were selected for dissemination by the Centre National de Recherche Agronomique (CNRA) under the WAAP program. FHIA 21 and PITA 3 were mass propagated in Côte d'Ivoire using in vivo multiplication techniques and distributed from 2012 to 2016 to 10 plantain producer groups located in seven zones of this country.

2.2. Field Evaluation Varietal Mixture Trials. PITA 3 was introduced to Côte d'Ivoire in 1993 by IITA in partnership with CNRA for evaluation in an AMYT. In southern Côte d'Ivoire PITA 3, FHIA 21 and three local cultivars were assessed in the field for tolerance to black leaf streak disease [26] and response to nematodes (Radopholus similis and Pratylenchus coffeae) [27]. In Ghana, FHIA 21 was also evaluated for agronomic performance $[28,29]$. In 2013, the agronomic performance of FHIA 21, PITA 3, and "Orishele" was also investigated in a varietal mixture trial under natural black leaf streak disease infestation [30].

2.3. Hybrid Multiplication and Distribution. From 2012 to 2016, PITA 3 and FHIA 21 were massively propagated (Figure 3 ) and distributed to farmers in several regions of
Côte d'Ivoire, Benin, Burkina Faso, and Togo under WAAPP coordinated by CORAF.

\section{Field Trials and Palatability Testing}

3.1. Multisite, On-Farm, and Variety Mixture Trials. PITA 3 and FHIA 21 bred in the 1980s and distributed in the 1990s were selected based on their host plant resistance to $P$. fijiensis, pendulous bunch orientation, large bunch, parthenocarpic fruit development, and improved ratooning that ensures rapid cycling. PITA 3 consistently out-yielded the medium-sized French plantain cultivars ("Obino L'Ewai" and "Bobby Tannap") in all the on-site early evaluation trials and multilocation trials [20]. On-farm fruit yields are estimated at $20 \mathrm{t} \cdot \mathrm{ha}^{-1}$ and $30 \mathrm{t} \cdot \mathrm{ha}^{-1}$ for PITA 3 and FHIA 21, respectively. The results obtained by Seydou et al. [30] indicate that PITA 3 and FHIA 21 were the most tolerant to black leaf streak disease with yields of 18.5 and $21.2 \mathrm{t} \cdot \mathrm{ha}^{-1}$, respectively, while the plantain cultivar "Orishele" was the most sensitive and least productive with a yield of $11.5 \mathrm{t} \cdot \mathrm{ha}^{-1}$ in the first crop cycle [26]. The number of hands per bunch was the same for the three accessions while the number of fruits (fingers) per bunch varied significantly ( $57 \pm 2.4$ for PITA 3, 71.6 \pm 3 for FHIA 21, and 33.4 $\pm 3.5 \mathrm{~g}$ for "Orishele"). Conversely, the average fruit weight of "Orishele" 


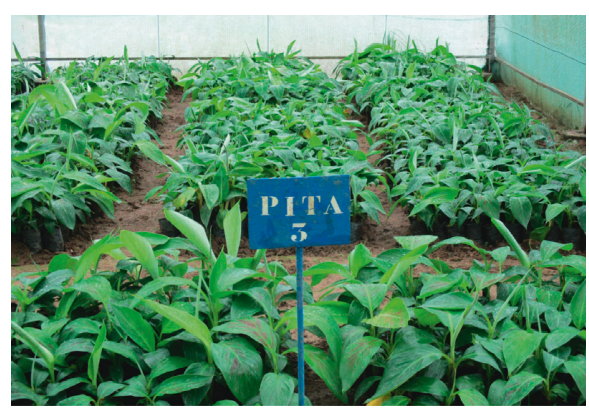

(a)

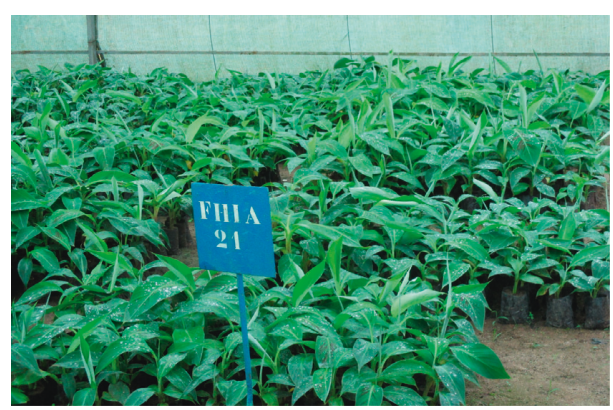

(b)

Figure 3: Seedlings of PITA 3 and FHIA 21 grown in the nursery prior to distribution and field transplanting in Côte d'Ivoire.

$(221 \pm 11 \mathrm{~g})$ was significant above that of PITA $3(159 \pm 6 \mathrm{~g})$ and FHIA 21 (152 $\pm 10 \mathrm{~g})$. The number of functional leaves at flowering was significantly higher in the hybrids $(13 \pm 0.5$ for PITA 3 and $13.4 \pm 0.4$ for FHIA 21) than the plantain cultivar "Orishele" (9.2 \pm 0.2$)$. Similarly, the number of functional leaves at harvest was significantly different among hybrids and cultivar: $6.4 \pm 0.4,4.6 \pm 0.2$ and $1 \pm 0.1$ for FHIA 21, PITA 3 and "Orishele," respectively [26]. In Ghana, FHIA 21 (named "Apem hemaa") was superior to the local cultivars both in agronomic traits and fruit productivity [29]. The result of the host plant response to nematodes revealed that FHIA 21 is resistant to $R$. similis and susceptible to P. coffeae, while PITA 3 is susceptible to both parasitic nematodes in Côte d'Ivoire [27]. The results observed in the varietal mixture trial showed significant differences between the number of functional leaves at flowering and harvest, the bunch weight, and fruit traits of the plantain cultivar "Orishele." The varietal combination of resistant and susceptible genotypes influenced the disease pressure in the trial plot and enhanced the yield of the landrace [31].

The bunch weight and yield potential of FHIA 21, PITA 3, and a giant false horn plantain cultivar "Big Ebanga" in Côte d'Ivoire, Burkina Faso, and Benin are shown in Figures 4-6, respectively. Yield potential (YLD, $\mathrm{t} \cdot \mathrm{ha}^{-1} \mathrm{year}^{-1}$ ) was defined as $(\mathrm{YLD}=\mathrm{BW} \times 365 \times 1667 /(\mathrm{DH} \times 1000))$, where $\mathrm{BW}$ and $\mathrm{DH}$ are bunch weight and days to harvest, while 365 and 1667 refer to days per year and plant density per hectare. Both plantain hybrids have a faster ratoon cycling and are more sustainable than the plantain cultivar, whose bunch yield declined after the first crop cycle. In Benin, the average yield of local plantains in farmer's field was 4 to $7 \mathrm{t} \cdot \mathrm{ha}^{-1}$, thus making both hybrids the most preferred by farmers. PITA 3 had acceptable cooking qualities when utilized to prepare the local plantain recipes (foutou, alloco, foufou, and ragout) in Côte d'Ivoire and when boiled green and fried when ripe as dodo in Nigeria [20]. In Ghana, FHIA 21 ranked best in terms of yield, palatability for ampesi (a local dish), and commercial potential [28].

3.2. Hybrid Multiplication and Dissemination. In the context of improving the productivity of plantain in Côte d'Ivoire, CNRA selected and started disseminating two tetraploid plantain hybrids FHIA 21 and PITA 3, for both their high fruit productivity and host plant resistance to black leaf

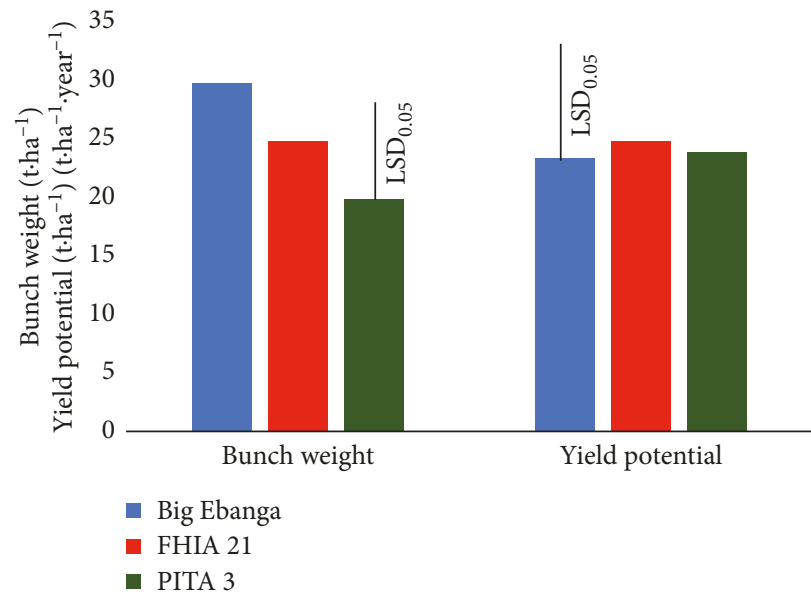

FIgURE 4: Bunch harvest $\left(\mathrm{t} \cdot \mathrm{ha}^{-1}\right.$ ) and yield potential (bunch weight $\mathrm{ha}^{-1} \cdot$ year $^{-1}$ ) of medium-sized tetraploid plantain hybrids FHIA 21 (ratoon cycle: 12 months) and PITA 3 (ratoon cycle: 10 months) along with giant false horn plantain "Big Ebanga" (ratoon cycle: +15 months) in Côte d'Ivoire.

streak disease. The large-scale distribution of these hybrids was carried out between 2012 and 2016 in several regions of Côte d'Ivoire. The distribution of PITA 3 and FHIA 21 from 2012 to 2016 in Côte d'Ivoire is shown in Figure 7. Approximately 92,680 PITA 3 and FHIA 21 seedlings were distributed free of charge to more than 160 producer groups between 2012 and 2014 .

In vivo macropropagation techniques using shelled corms facilitated the availability of healthy planting materials of plantain cultivars and hybrids. The further use of $40 \mathrm{mg} \cdot \mathrm{l}^{-1}$ benzylaminopurine (BAP) on macropropagation led to PITA 3, producing the highest number of shoots per corm compared to the plantain cultivars [31], thus showing the advantage of adding BAP for increasing sucker production in this plantain hybrid.

\section{Advances in Deploying Plantain Breeding Outputs in West Africa}

Major progress has been made by the plantain and bananabreeding programs in developing high-yielding resistant plantain hybrids $[32,33]$. The tetraploid hybrids PITA 3 and FHIA 21 phenotypically resemble their respective female 


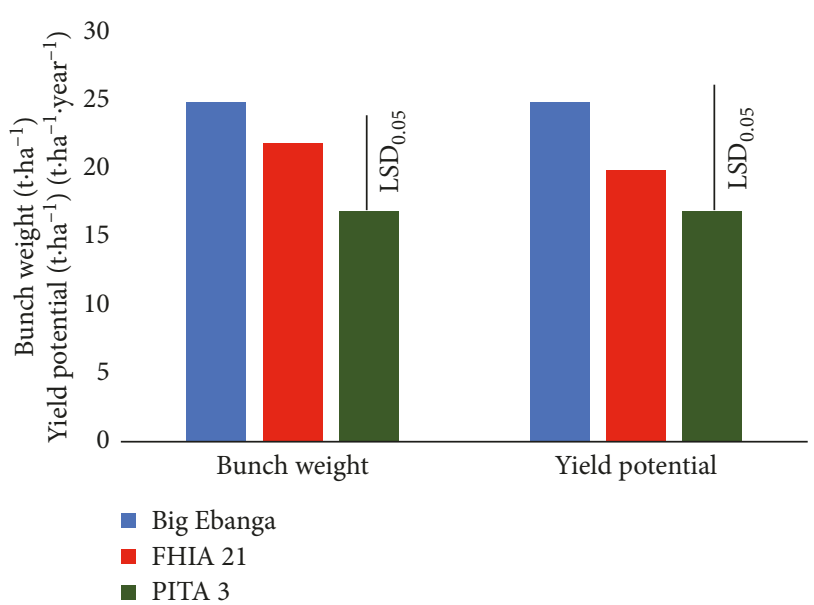

FIGURE 5: Bunch harvest (t.ha ${ }^{-1}$ ) and yield potential (bunch weight $\mathrm{ha}^{-1} \cdot$ year $^{-1}$ ) of medium-sized tetraploid plantain hybrids FHIA 21 (growth cycle: 13 months) and PITA 3 (growth cycle: 12 months) along with giant false horn plantain "Big Ebanga" (growth cycle: 12 months) recorded in $120 \mathrm{~m}^{2}$ plots at Bobo Dioulasso, Burkina Faso.

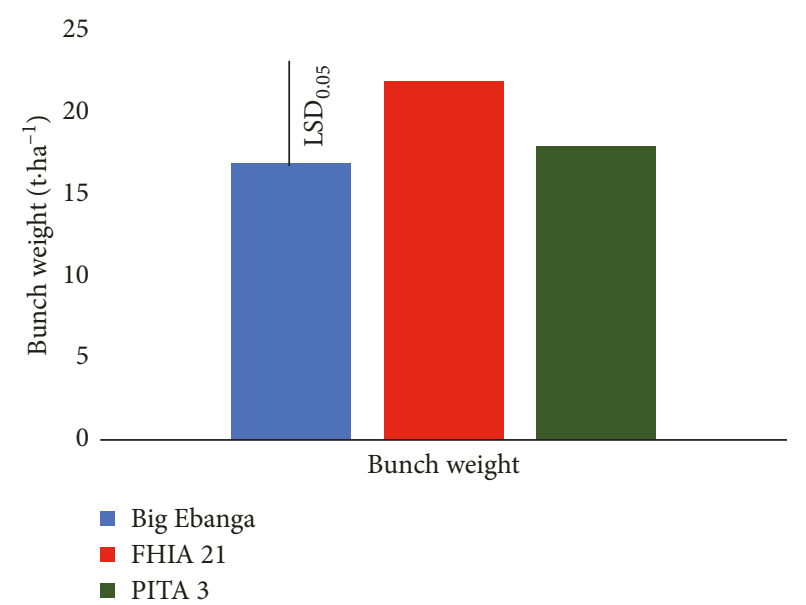

FIgURE 6: Bunch harvest $\left(\mathrm{t} \cdot \mathrm{ha}^{-1}\right.$ ) of medium-sized tetraploid plantain hybrids FHIA 21 and PITA 3 along with giant false horn plantain "Big Ebanga" at advanced yield trial using 3 replications at a plant density of $3 \mathrm{~m} \times 2 \mathrm{~m}$ in Benin. The average yield of plantain on family farms in this country remains very low: from 4 to $7 \mathrm{t} \cdot \mathrm{ha}^{-1}$.

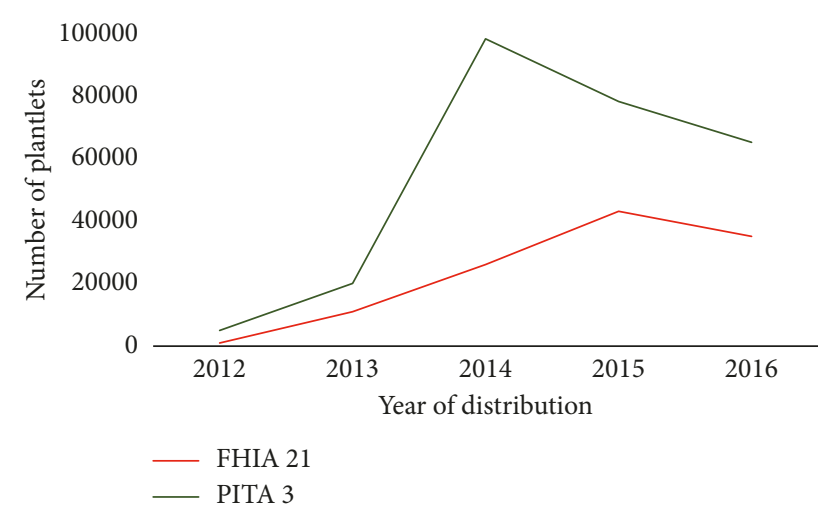

FIgURE 7: Distribution of in vivo plants of plantain tetraploid hybrids PITA 3 and FHIA 21 from 2012 to 2016 in Côte d'Ivoire. plantain parents but exhibit shorter plant height, rapid cycling, better fruit productivity, and regulated suckering behavior, which are highly desirable characteristics for perennial plantain production. The plantain hybrids are female- and male-fertile and can be also utilized as parents in $4 x \times 2 x$ crosses to produce secondary triploid hybrids.

IITA in Nigeria, CARBAP in Cameroon, and FHIA in Honduras have made available to plantain growers hybrids that are resistant or tolerant to black leaf streak disease [16-18]. PITA 3 and FHIA 21 plantain hybrids evaluated in various West African sites had better fruit productivity $[20,34]$ and sucker production [32] than local cultivars. This on-station evaluation was followed by participatory selection trials with all the introduced hybrids and the plantain cultivars such as "Big Ebanga" and "Orishele." The criteria for selection were their bunch weight and fruit taste when processed into local dishes. Based on their bunch productivity and cooking characteristics, PITA 3 and FHIA 21 were selected by the growers. As part of a research project on the sustainable improvement of the plantain sector in West Africa, these hybrids were massively propagated and distributed to farmers in several regions of Côte d'Ivoire, Benin, Burkina Faso, and Togo under WAAPP coordinated by CORAF. In 2016, CNRA included PITA 3 and FHIA 21 in the varietal directory of improved cultivars of Côte d'Ivoire, which shows that the hybrids have acceptable agronomic and taste attributes.

The utilization of the plantain hybrids in mixed cropping with local cultivars in Côte d'Ivoire was very effective in reducing black leaf streak disease pressure on the susceptible local cultivars, thereby raising the number of functional leaves at flowering that translated into increasing fruit yield [30]. The same approach was used for large-scale distribution of improved hybrids in Nigeria and Cameroon where bunch weights increased from $4.9 \mathrm{~kg}$ to 7.1 or $8.1 \mathrm{~kg}$ in sole and mixed cropping, respectively. This strategy for hybrid dissemination preserves genetic diversity while exposing farmers to high-yielding resistant hybrids for adoption $[17,35]$.

\section{Conclusion}

About 27 years elapsed from the crossing made in 1989 that resulted in PITA 3 and its registration in Côte d'Ivoire in 2016 (Table 1), 12 of which are attributed to the technicalities of breeding by the breeding program and 15 years for on farm testing and mass multiplication and registration attributed to the work of the national program.

In the past three decades, significant progress has been made in breeding high-yielding disease-resistant plantain hybrids with fruit-eating quality similar to some West African plantain cultivars. The fruit productivity and rapid cycling of plantain tetraploid hybrids PITA 3 and FHIA 21 indicate that they have a high adoption potential and may impact on plantain production in the humid lowland agroecology of West Africa. Indeed, as shown by an ex ante impact assessment of using black leaf streak-resistant plantains a 10:1 cost-benefit advantage may be provided by the plantain hybrids vis-à-vis fungicides in the main 
TABle 1: The making of PITA 3: from crossing (1989) to cultivar release in Côte d'Ivoire (2016).

\begin{tabular}{|c|c|}
\hline Year & Activity \\
\hline 1989 & $\begin{array}{r}\text { Crossing of tetra } \\
\text { wilc }\end{array}$ \\
\hline 1990 & $\begin{array}{l}\text { In vitro seed germination, } \\
\text { evaluation trial planting a } \\
\text { (Onne, Rivers }\end{array}$ \\
\hline 1990 & $\begin{array}{r}\text { Early and preliminary yie } \\
\text { st }\end{array}$ \\
\hline 1993 & $\begin{array}{r}\text { Multisite trials of plan } \\
\text { ratoon cro }\end{array}$ \\
\hline $\begin{array}{l}1994 \\
\text { onwards }\end{array}$ & $\begin{array}{r}\text { Advanced yield t } \\
\text { (PITA } 3 \text { amo } \\
\text { (in }\end{array}$ \\
\hline 97 & Tecting of $f_{1}$ \\
\hline & rm testing began in Côte d'Ivoire \\
\hline 2 & $\begin{array}{c}\text { Mass propagation and in vivo distribution in Côte } \\
\text { d'Ivoire }\end{array}$ \\
\hline 20 & \\
\hline 2017 & $\begin{array}{r}\text { PITA } 3 \text { included in } \\
\text { culti }\end{array}$ \\
\hline
\end{tabular}

producing season in the Nigerian plantain belt, while it may be $5.5: 1$ when plantains are not in high supply ([36]). Furthermore, host plant resistance in plantain hybrid breeding leads to both increased fruit yield and cash income in smallholder management systems [37]. The dissemination and acceptance of these plantain hybrid cultivars by growers will therefore enhance the sustainable intensification in plantain-based farming systems therein, i.e., increasing steady harvests of plantain fruit from existing farmlands and orchards.

\section{Disclosure}

The research article "Measuring the impact of plant breeding on sub-Saharan African staple crops" by Eriksson et al. in Outlook on Agriculture (vol. 47, pp. 163-180, 2018) cites Tenkouano et al. "Disseminating promising high-yielding tetraploid plantain bred-hybrids in West Africa," which is an abstract of a talk given by corresponding author at FOOD 2030 International Congress: Towards Sustainable Agri-Food Systems (University of Hohenheim, Germany, 5-6 September 2018. University of Hohenheim, Germany, p. 20, 2018) and based on the research results included herein.

\section{Conflicts of Interest}

The authors declare that there are no conflicts of interest regarding the publication of this paper.

\section{Acknowledgments}

Financial support from the World Bank and the Economic Commission of West African States is gratefully acknowledged by CORAF for disseminating plantain hybrids in the humid lowlands of Africa. The authors wish to acknowledge all the partners that were involved in the field trials and those that facilitated the multiplication and dissemination of the plantain-bred tetraploid hybrids in Côte d'Ivoire, Benin, Burkina Faso, and Togo.

\section{References}

[1] R. Swennen, D. Vuylsteke, and R. Ortiz, "Phenotypic diversity and patterns of variation in West and Central African plantains (Musa spp., AAB group Musaceae)," Economic Botany, vol. 49, no. 3, pp. 320-327, 1995.

[2] J. Adheka, J. Komoy, C. Tamaru et al., "Banana diversity in the oriental provinces, north-eastern Democratic Republic of Congo," Acta Horticulturae, vol. 1196, pp. 255-264, 2018.

[3] J. G. Adheka, D. B. Dhed'a, D. Karamura, G. Blomme, R. Swennen, and E. De Langhe, "The morphological diversity of plantain in the Democratic Republic of Congo," Scientia Horticulturae, vol. 234, pp. 126-133, 2018.

[4] S. O. S. Akinyemi, I. O. O. Aiyelaagbe, and E. Akyeampong, "Plantain (Musa spp.) cultivation in Nigeria: a review of its production, marketing and research in the last two decades," Acta Horticulturae, vol. 879, pp. 211-218, 2010.

[5] R. Swennen, Plantain Cultivation under West Africa Conditions: A Reference Manual, International Institute of Tropical Agriculture (IITA), Ibadan, Nigeria, 1990.

[6] R. Ortiz and D. Vuylsteke, "Improving plantain and bananabased system," in Proceedings of a Regional Workshop on Plantain and Banana Production and Research in West and Central Africa, R. Ortiz and M. O. Akoroda, Eds., International Institute of Tropical Agriculture (IITA), Onne, Nigeria, September 1996.

[7] F. Nweke, J. Njoku, and G. F. Wilson, "Productivity and limitations of plantain (Musa spp. cv. AAB) production in compound gardens in Southeastern Nigeria," Fruits, vol. 43, no. 3, pp. 161-166, 1988.

[8] G. F. Wilson, "Status of bananas and plantain in West Africa," in Proceedings of an International Workshop on Banana and Plantain Breeding Strategies, G. J. Persley and E. A. De Langhe, Eds., vol. 21, pp. 29-35, ACIAR Proceedings, Cairns, Australia, October 1986.

[9] J. Chamberlin, "Defining smallholder agriculture in Ghana: who are smallholders, what do they do and how are they linked with markets?," Ghana Strategy Support Program (GSSP) Background Paper No. GSSP 0006, International Food Policy Research Institute (IFPRI), Washington, DC, USA, 2007.

[10] O. I. Baruwa, M. B. Masuku, and T. Alimi, "Economic analysis of plantain production in derived savanna zone of Osun state, Nigeria," Asian Journal of Agricultural Sciences, vol. 3, no. 5, pp. 401-407, 2011

[11] A. Viljoen, G. Mahuku, C. Massawe et al., Banana Diseases and Pests: Field Guide for Diagnostics and Data Collection, International Institute of Tropical Agriculture (IITA), Ibadan, Nigeria, 2017.

[12] A. E. Alakonya, J. Kimunye, G. Mahuku et al., "Progress in understanding Pseudocercospora banana pathogens and the development of resistant Musa germplasm," Plant Pathology, vol. 67, no. 4, pp. 759-770, 2018.

[13] K. N. Mobambo, F. Gauhl, D. Vuylsteke, R. Ortiz, C. PasbergGauhl, and R. Swennen, "Yield loss in plantain from black sigatoka leaf spot and field performance of resistant hybrids," Field Crops Research, vol. 35, no. 1, pp. 35-42, 1993.

[14] M. Zandjanakou-Tachin, P. S. Ojiambo, I. Vroh-Bi, A. Tenkouano, Y. M. Gumedzoe, and R. Bandyopadhyay, "Pathogenic variation of Mycosphaerella species infecting 
banana and plantain in Nigeria," Plant Pathology, vol. 62, no. 2, pp. 298-308, 2013.

[15] C. S. Gold, J. E. Pena, and E. B. Karamura, "Biology and integrated pest management for the banana weevil Cosmopolites sordidus (Germar) (Coleoptera: Curculionidae)," Integrated Pest Management Reviews, vol. 6, no. 2, pp. 79-155, 2001.

[16] D. Vuylsteke, R. Ortiz, S. Ferris, and R. Swennen, ““PITA-9”: a black-sigatoka-resistant hybrid from the "False Horn" plantain gene pool," HortScience, vol. 30, no. 2, pp. 395-397, 1995.

[17] A. Tenkouano and R. Swennen, "Progress in breeding and delivering improved plantain and banana to African farmers," Chronica Horticulturae, vol. 44, pp. 9-15, 2004.

[18] S. Dépigny, P. Noupadja, K. Tomekpe, P. Bonneviot, T. Lescot, and F. Bakry, “'CARBAP K74”: a triploid plantain-like hybrid designed to promote sustainable plantain-based cropping systems," Acta Horticulturae, vol. 1196, pp. 63-70, 2018.

[19] D. Vuylsteke, R. Swennen, and R. Ortiz, "Registration of 14 improved tropical Musa plantain hybrids with black sigatoka resistance," HortScience, vol. 28, no. 9, pp. 957-959, 1993.

[20] R. Ortiz, D. Vuylsteke, R. S. B. Ferris et al., "Developing new plantain varieties for Africa," Plant Varieties and Seeds, vol. 10, pp. 39-57, 1997.

[21] International Institute of Tropical Agriculture (IITA), Improving Plantain- and Banana-Based Systems. Project 2 Annual Report, International Institute of Tropical Agriculture (IITA), Ibadan, Nigeria, 2000.

[22] A. Tenkouano, M. Pillay, and R. Ortiz, "Breeding techniques," in Banana Breeding Progress and Challenges, M. Pillay and A. Tenkouano, Eds., pp. 181-200, CRC Press, Boca Raton, Florida, 2011.

[23] D. R. Vuylsteke, R. L. Swennen, and R. Ortiz, "Development and performance of black sigatoka-resistant tetraploid hybrids of plantain (Musa spp., AAB group)," Euphytica, vol. 65, no. 1, pp. 33-42, 1993.

[24] R. Swennen and D. Vuylsteke, "Breeding black sigatoka resistant plantains with a wild banana," Tropical Agriculture, vol. 70, pp. 74-77, 1993.

[25] R. Ortiz, R. S. B. Ferris, and D. Vuylsteke, "Banana and plantain breeding," in Bananas and Plantains, S. Gowen, Ed., pp. 110-146, Chapman \& Hall, London, UK, 1995.

[26] S. Tuo, A. L.-N. D. Elisee, B. Camara et al., "Assessment of banana and plantain behavior under natural infestation by Mycosphaerella fijiensis, Morelet in Southern Côte d'Ivoire," Journal of Agronomy, vol. 15, no. 4, pp. 151-164, 2016.

[27] O. S. T. Vawa, A. Otchoumou, A. Adiko, and G. P. Otchoumou, "Host status of plantain hybrids FHIA 21 and PITA 3 for populations of Radopholus similis and Pratylenchus coffeae in Côte d'Ivoire," Greener Journal of Agricultural Sciences, vol. 6, no. 9, pp. 262-271, 2016.

[28] B. M. Dzomeku, M. D. Quain, J. N. L. Lamptey, F. O. AnnoNyako, A. Aubyn, and S. K. Darkey, "Agronomic and sensory evaluation of some IITA hybrids in Ghana," International Journal of Agricultural Research, vol. 2, no. 3, pp. 307-311, 2007.

[29] B. M. Dzomeku, A. A. Ankomah, and S. K. Darkey, "Agronomic performance of two tetraploid hybrid plantains in Ghana," Agriculturae Conspectus Scientificus, vol. 74, no. 3, pp. 309-312, 2009.

[30] T. Seydou, A. Ler-N`ogn, C. Mamadou et al., “Agronomic performance of plantain cultivars (Musa spp.) in efficient mixing situation for the control of black sigatoka in southern Côte d'Ivoire," Asian Journal of Plant Pathology, vol. 11, pp. 1-9, 2017.
[31] D. E. F. Thiemele, A. E. Issali, S. Traore et al., "Macropropagation of plantain (Musa spp.) cultivars PITA 3, FHIA 21, ORISHELE and CORNE 1: effect of benzylaminopurine (BAP) concentration," Journal of Plant Development, vol. 22, pp. 31-39, 2015.

[32] R. Ortiz, "Conventional banana and plantain breeding," Acta Horticulturae, vol. 986, pp. 177-194, 2013.

[33] R. Ortiz and R. Swennen, "From crossbreeding to biotechnology-facilitated improvement of banana and plantain," Biotechnology Advances, vol. 32, no. 1, pp. 158-169, 2014.

[34] S. Traore, K. Kobenan, K. E. Kendia, D. Kone, and D. Traore, "Relation entre densite stomatique et reaction a la maladie des raies noires chez differents genotypes de bananiers et de bananiers plantains," Agronomie Africaine, vol. 20, no. 1, pp. 37-47, 2008.

[35] A. Tenkouano, B. O. Faturoti, and K. P. Baiyeri, "On farm evaluation of Musa hybrids in Nigeria," Tree and Forestry Science and Biotechnology, vol. 1, pp. 30-34, 2009.

[36] D. Eriksson, M. Akoroda, G. Azmach, M. Labuschagne, N. Mahungu, and R. Ortiz, "Measuring the impact of plant breeding on sub-Saharan African staple crops," Outlook on Agriculture, vol. 47, no. 3, pp. 163-180, 2018.

[37] J. I. Lemchi, C. I. Ezedinma, M. Tshiunza, A. Tenkouano, and B. O. Faturoti, "Agroeconomic evaluation of black sigatoka resistant hybrid plantains under smallholder management systems," African Journal of Biotechnology, vol. 4, no. 10, pp. 1045-1053, 2005. 


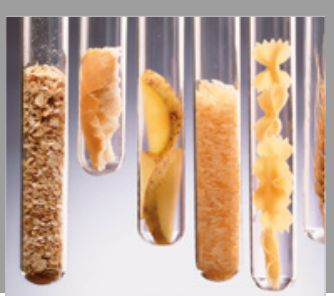

International Journal of Food Science

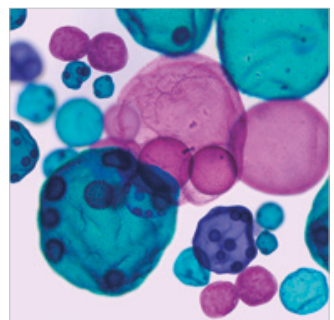

International Journal of Microbiology
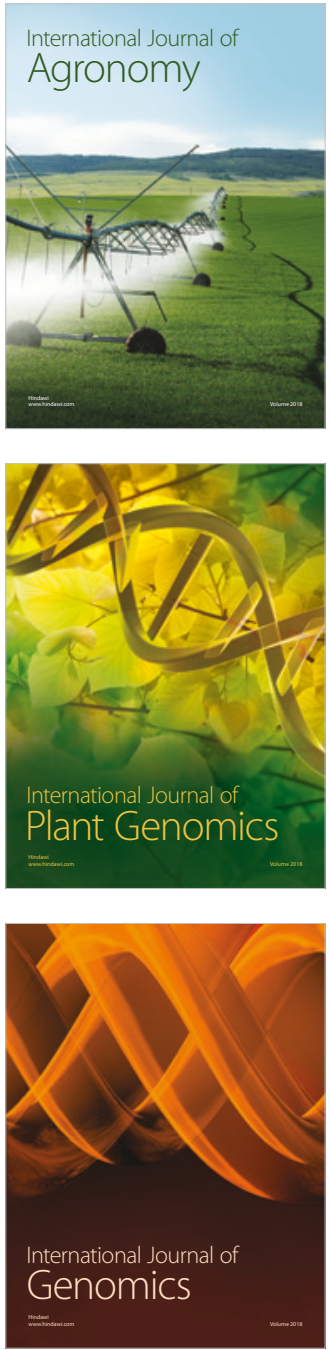

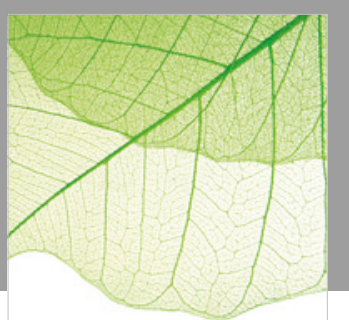

Journal of Botany
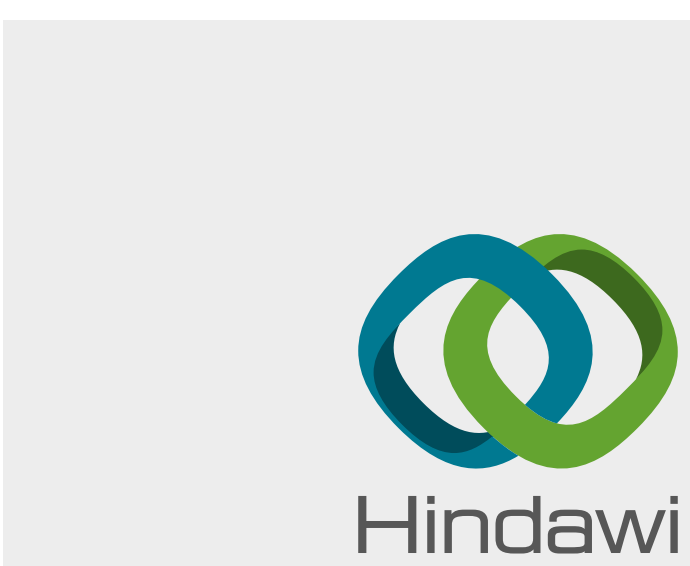

Submit your manuscripts at

www.hindawi.com
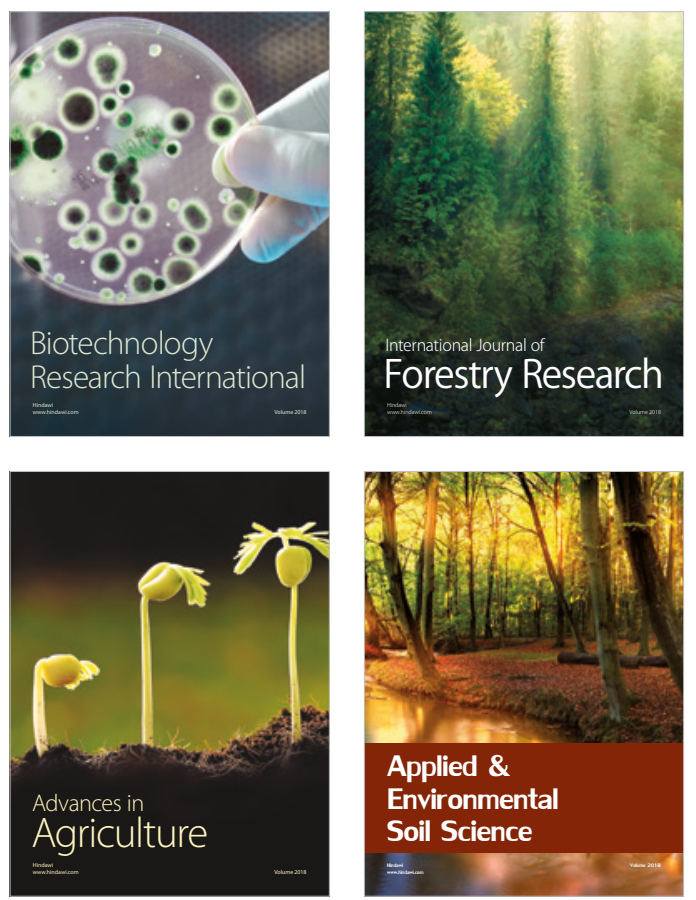

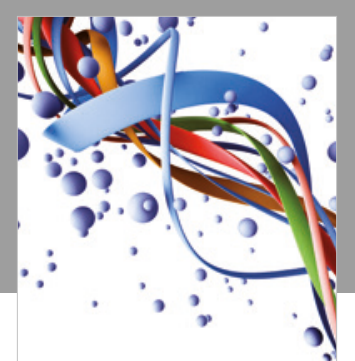

Scientifica

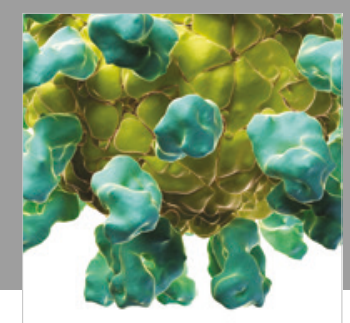

Veterinary Medicine International

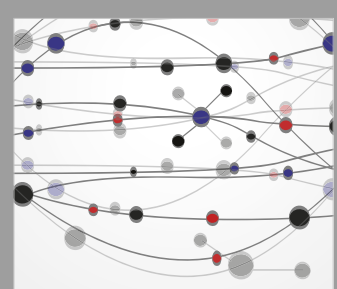

The Scientific World Journal
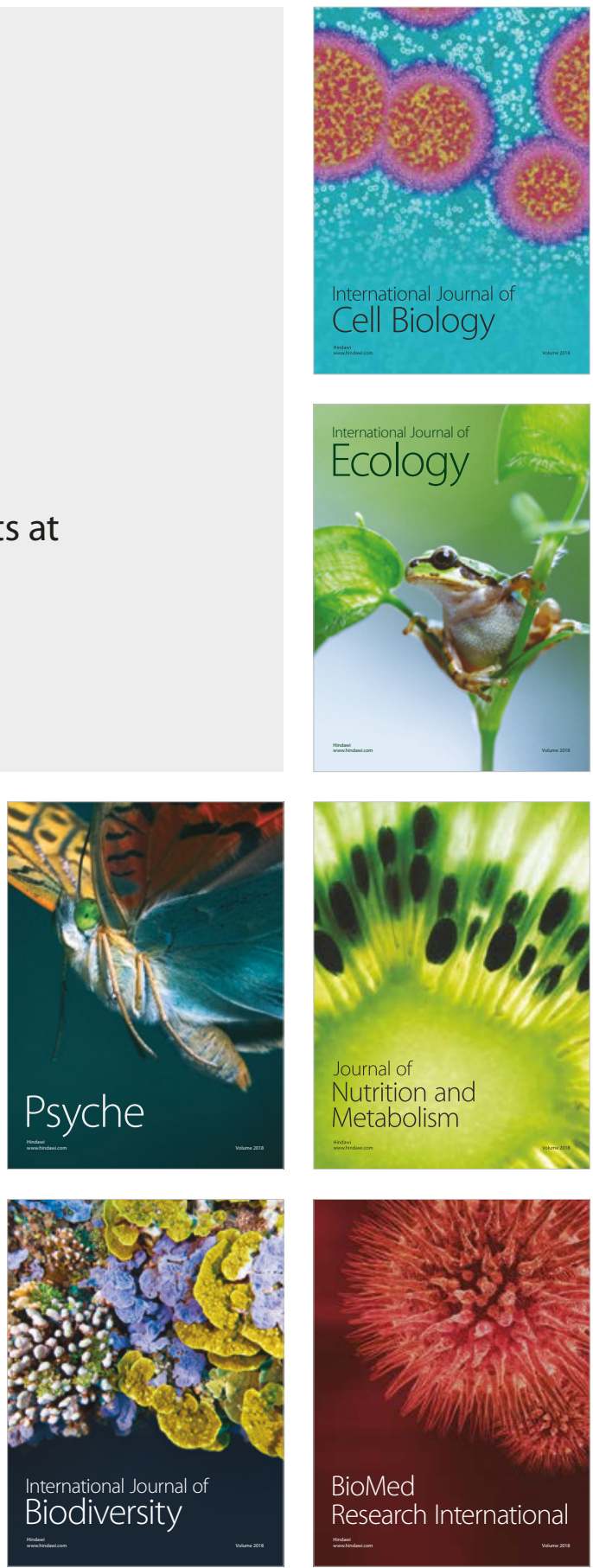